\title{
Ascochytatin, a Novel Bioactive Spirodioxynaphthalene Metabolite Produced by the Marine-derived Fungus, Ascochyta sp. NGB4
}

\author{
Kaneo Kanoh, Ario Okada, Kyoko Adachi, Hiroshi Imagawa, Mugio Nishizawa, \\ Satoru Matsuda, Yoshikazu Shizuri, Ryutaro Utsumi
}

Received: January 28, 2008 / Accepted: February 26, 2008

(C) Japan Antibiotics Research Association

\begin{abstract}
Ascochytatin, a new spirodioxynaphthalene metabolite produced by a marine-derived fungus, was found from a screening program focused on the bacterial two-component regulatory system. The structure of ascochytatin was determined by spectroscopic methods, including NMR and MS. The relative stereochemistry was determined by an X-ray crystallographic analysis, and the absolute stereochemistry was determined by the modified Mosher's method.
\end{abstract}

Keywords marine-derived fungus, ascochytatin, twocomponent regulatory system, modified Mosher's method

\section{Introduction}

The two-component regulatory system (TCS) of bacteria, which consists of two proteins, a histidine kinase (HK) and a response regulator (RR), has received increasing attention for its potential as a novel antibacterial drug target [1], and a number of TCS autophosphorylation inhibitors with inhibitory activity against multi-drug-resistant bacteria have been reported [2 4]. TCS is a fundamental system of bacterial response to environmental stress in both Gramnegative and Gram-positive bacteria, and most TCSs are not necessarily essential for steady-state growth without stress. However, a small number of TCS-encoding genes have been found to be essential; for instance, a set of YycG (HK) and YycF (RR) is the essential TCS in Bacillus subtilis and Staphylococcus aureus. A sensitive screening method for antibacterial agents that inhibit $\mathrm{YycG} / \mathrm{YycF}$ has been developed. This utilizes a temperature-sensitive $y y c F$ mutant (CNM2000) of B. subtilis, and aranorosinol B was found to be a $\mathrm{YycG}$ inhibitor by this screening method in an earlier study [5]. Continued screening for new YycG/YycF inhibitors enabled us to find ascochytatin (1), a new spirodioxynaphthalene metabolite produced by a marine-derived fungus. The producing fungus, isolation, structural determination, including the absolute stereochemistry, and some biological activities of $\mathbf{1}$ are described in this paper.

\section{Materials and Methods}

\section{Microorganism}

The marine-derived fungus, Ascochyta sp. NGB4, was isolated from a floating scrap of festering rope that had been collected at a fishing port in Nagasaki prefecture,

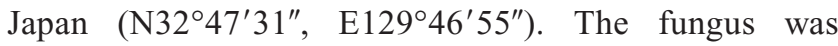

K. Kanoh (corresponding author), K. Adachi, S. Matsuda, Y. Shizuri: Marine Biotechnology Institute Co., Ltd., 3-75-1 Heita, Kamaishi, Iwate 026-0001, Japan, E-mail: kaneo.kanoh@mbio.jp H. Imagawa, M. Nishizawa: Faculty of Pharmaceutical Science, Tokushima Bunri University, Yamashiro-cho, Tokushima 7708514, Japan
A. Okada, R. Utsumi: Department of Bioscience and Biotechnology, Graduate School of Agriculture, Kinki University, 3327-204, Nakamachi, Nara 631-8505, Japan 
cultured and kept on potato dextrose agar (Difco) prepared in 50\% natural seawater. This strain has been deposited as NITE AP-488 at the NITE Patent Microorganisms Depositary (NPMD), Japan.

\section{Taxonomic Studies}

The following media were used to identify the producing fungus: potato dextrose agar (PDA), 2.0\% malt agar (MA), oatmeal agar (OA), Miura's medium (LcA), and corn meal agar (CMA). The formed colonies were observed after a two-week incubation at $25^{\circ} \mathrm{C}$. The color names used in this study were taken from Kornerup and Wanscher [6].

\section{Bioassay Using B. subtilis 168 and CNM2000 [5]}

In order to search for the TCS inhibitors, each sample (i.e. the $\mathrm{Me}_{2} \mathrm{CO}$ extract of a cultured fungus) was spotted on trypticase soy $(0.75 \%)$ agar $(1.5 \%)$ plates that had been overlaid with $3.0 \mathrm{ml}$ of top agar $(0.5 \%)$ containing $30 \mu \mathrm{l}$ of an overnight culture of B. subtilis 168 or CNM2000. After 24 hours of the incubation at $37^{\circ} \mathrm{C}$, the diameter of inhibition zone of each strain was measured. In screening for TCS inhibitors, those samples that inhibited the growth of CNM2000 more strongly than that of 168 were selected.

\section{Culture and Isolation}

Ascochyta sp. NGB4 as the seed culture was cultured at $25^{\circ} \mathrm{C}$ at a rotation speed of $100 \mathrm{rpm}$ for 7 days in potato dextrose broth (Difco) that had been prepared with 50\% seawater. One-ml samples of the seed culture were inoculated on the production agar medium $(400 \mathrm{ml})$ in stainless steel plates $(320 \times 190 \mathrm{~mm})$. The composition of the agar medium is as follows: glucose, $0.5 \%$; glycerol, $2.0 \%$; yeast extract, $0.2 \%$; Pharmamedia ${ }^{\circledR}$ (Traders Protein), 2.0\%; $\mathrm{NaCl}, 0.25 \%$; and agar, $1.5 \%$; and adjusted to $\mathrm{pH} 6.5$ before autoclaving. After incubating at $25^{\circ} \mathrm{C}$ for 14 days, the cultured agar medium (8.0 liters) was extracted with $\mathrm{Me}_{2} \mathrm{CO}$. The extract was evaporated to remove the $\mathrm{Me}_{2} \mathrm{CO}$, and the aqueous residue ( $c a .2 .0$ liters) was extracted twice with an equal volume of EtOAc. The extract was concentrated in vacuo and chromatographed on a silica gel column by a stepwise elution with mixtures of $\mathrm{CHCl}_{3} / \mathrm{MeOH}: \mathrm{MeOH} 0,1,10$ and $100 \%$. The $1.0 \%$ $\mathrm{MeOH}-\mathrm{CHCl}_{3}$ fraction, which exhibited stronger inhibitory activity toward B. subtilis CNM2000 than 168, was further purified by a silica gel column chromatography using hexane/EtOAc $(1: 1)$ as the eluent. The active fractions were collected and evaporated in vacuo to yield $80 \mathrm{mg}$ of 1 as a white powder. Half of this powder was crystallized from $\mathrm{MeOH}$ for an X-ray crystallographic analysis, yielding colorless needles (12 mg).

\section{General for Structural Determination}

UV spectra were recorded with a Beckman DU 640 spectrometer and IR spectra with a JASCO FT/IR-430 instrument. Melting points were measured on Yanagimoto apparatus. Optical rotations were measured on a Horiba SEPA-300. The ${ }^{1} \mathrm{H}$ - and all 2D NMR spectra were recorded with a Varian Unity INOVA 750 instrument at $750 \mathrm{MHz}$, and the ${ }^{13} \mathrm{C}-\mathrm{NMR}$ spectrum was recorded with a Varian Unity INOVA 500 instrument at $125 \mathrm{MHz}$. Chemical shifts are referenced to the solvent peaks of $\delta_{\mathrm{H}} 3.31$ and $\delta_{\mathrm{C}} 49.15$ for $\mathrm{CD}_{3} \mathrm{OD}$, and $\delta_{\mathrm{H}} 7.25$ and $\delta_{\mathrm{C}} 77.0$ for $\mathrm{CDCl}_{3}$. Low- and high-resolution FAB-MS data were obtained with a JEOL JMS700 spectrometer, and ESI-MS data were measured with a ThermoFinigan LCQ Advantage instrument.

\section{X-Ray Crystallographic Analysis}

The crystal used for the X-ray crystallographic analysis was obtained by crystallization from $\mathrm{MeOH}$. Crystal data for $\mathbf{1}$ : $\mathrm{C}_{40} \mathrm{H}_{28} \mathrm{O}_{14}$ (for two molecules), colorless needle, $M_{\mathrm{r}}=732.62, \quad$ monoclinic, $P 2(1), \quad a=12.8150(14) \AA$, $b=8.2858(9) \AA, \quad c=15.6756(18) \AA, \quad \alpha=90^{\circ}, \quad \beta=$ $109.9230(10)^{\circ}, \quad \gamma=90^{\circ}, \quad V=1564.9(3) \AA^{3}, \quad Z=2$, $\rho_{\text {calcd. }}=1.555 \mathrm{Mg} \mathrm{m}^{-3}, \quad \mu=0.158 \mathrm{~mm}^{-1}, \quad T=100 \mathrm{~K}, 8976$ measured reflections, $4549[R($ int $)=0.0434]$ independent reflections, 495 parameters, $\mathrm{GOF}=1.013$, and $R 1$ $(w R 2)=0.0611(0.1581)$. The measurements were made with a Bruker-AXS SMART Apex II CCD system with $\operatorname{Mo} K_{\alpha}$ radiation $(\lambda=0.71073 \AA)$ at $100 \mathrm{~K}$. The crystal structure was solved by direct methods and refined by a full matrix least squares operation on $\mathrm{F}^{2}$ with SHELXTL. Absorption corrections were applied with SADABS. CCDC 669952 contains supplementary crystallographic data to those reported here. These data can be obtained free of charge from The Cambridge Crystallographic Data Centre via www.ccdc.cam.ac.uk/data_request/cif.

\section{Trimethylascochytatin (2)}

To a solution of $1(5.0 \mathrm{mg}, 13.6 \mu \mathrm{mol})$ in a $\mathrm{CHCl}_{3} / \mathrm{MeOH}$ $(5: 1)$ mixture $(2.0 \mathrm{ml})$ was added an excess amount of trimethylsilyldiazomethane (Tokyo Chemical Industry Co.). After stirring at ambient temperature for 36 hours, the reaction mixture was evaporated to dryness, and the residue was chromatographed on a silica gel column (i.d. $10 \times 150 \mathrm{~mm})$, eluting with hexane/EtOAc $(2: 1)$ to afford 2 (3.5 mg). Compound 2: white solid; TLC Rf value 0.7 $\left(\mathrm{CHCl}_{3} / \mathrm{MeOH}(10: 1)\right)$ and 0.2 (hexane/EtOAc $\left.(1: 1)\right) ;{ }^{1} \mathrm{H}-$ NMR (750 MHz, $\left.\mathrm{CDCl}_{3}\right): 3.71(1 \mathrm{H}, \mathrm{t}, 3.8, \mathrm{H}-3), 3.67(1 \mathrm{H}$, d, 3.8, H-2), $3.69\left(3 \mathrm{H}, \mathrm{s}, 8-\mathrm{O}-\mathrm{CH}_{3}\right), 3.92\left(3 \mathrm{H}, \mathrm{s}, 5-\mathrm{O}-\mathrm{CH}_{3}\right)$, $3.98\left(3 \mathrm{H}, \mathrm{s}, 4^{\prime}-\mathrm{O}-\mathrm{CH}_{3}\right), 4.26(1 \mathrm{H}, \mathrm{br}$ s, $4-\mathrm{OH}), 5.38(1 \mathrm{H}$, br s, H-4), $6.80\left(1 \mathrm{H}, \mathrm{d}, 9.0, \mathrm{H}-3^{\prime}\right) 6.95\left(1 \mathrm{H}, \mathrm{d}, 8.3, \mathrm{H}-7^{\prime}\right)$, $6.98\left(1 \mathrm{H}, \mathrm{d}, 9.0, \mathrm{H}-2^{\prime}\right), 6.99(2 \mathrm{H}, \mathrm{s}, \mathrm{H}-6$ and $\mathrm{H}-7$ 
overlapping), $7.41\left(1 \mathrm{H}, \mathrm{t}, 8.3, \mathrm{H}-6^{\prime}\right), 7.82(1 \mathrm{H}, \mathrm{d}, 8.3, \mathrm{H}-$ $\left.5^{\prime}\right) ;{ }^{13} \mathrm{C}-\mathrm{NMR}\left(125 \mathrm{MHz}, \mathrm{CDCl}_{3}\right): 53.12(\mathrm{C}-2), 54.21$ (C$3), 55.86\left(4^{\prime}-\mathrm{O}-\mathrm{CH}_{3}\right), 56.26\left(5-\mathrm{O}-\mathrm{CH}_{3}\right), 57.86\left(8-\mathrm{O}-\mathrm{CH}_{3}\right)$, 63.71 (C-4), 96.73 (C-1), 105.53 (C-3'), 108.82 (C-2'), $109.67\left(\mathrm{C}-7^{\prime}\right), 113.11$ (C-8a', interchangeable with $\left.\mathrm{C}-6\right)$, 113.19 (C-6, interchangeable with C-8a'), 115.29 (C-7), 115.39 (C-5'), 121.97 (C-8a), 125.41 (C-4a), 125.89 (C$\left.4 \mathrm{a}^{\prime}\right), 126.49$ (C-6'), $140.74\left(\mathrm{C}-1^{\prime}\right), 147.37$ (C-8'), 150.05 (C-4'), 151.83 (C-5), 154.32 (C-8).

\section{(R)-MTPA Ester (3)}

To a solution of $2(1.5 \mathrm{mg}, 3.7 \mu \mathrm{mol})$ in pyridine $(100 \mu \mathrm{l})$ was added (+)-(S)-MTPACl (15 $\mu$ l, Kanto Kagaku Co.). After stirring at ambient temperature for 14 hours, the reaction mixture was diluted with $\mathrm{CHCl}_{3}$ and then successively washed with aqueous $\mathrm{NaHCO}_{3}$ and saturated $\mathrm{NaCl}$. The organic layer was dried with $\mathrm{Na}_{2} \mathrm{SO}_{4}$ and evaporated to dryness, and the residue was chromatographed on a silica gel column (i.d. $10 \times 200 \mathrm{~mm}$ ), eluting with hexane/EtOAc $(2: 1)$ to afford $3(1.3 \mathrm{mg})$. Compound 3: white solid; TLC Rf value 0.4 (hexane/ EtOAc $(1: 1)) ;{ }^{1} \mathrm{H}-\mathrm{NMR}\left(750 \mathrm{MHz}, \mathrm{CDCl}_{3}\right): 3.50(3 \mathrm{H}, \mathrm{s}, 5-$ $\left.\mathrm{O}-\mathrm{CH}_{3}\right), 3.65\left(3 \mathrm{H}\right.$, br s, $-\mathrm{O}-\mathrm{CH}_{3}$ of MTPA), $3.69(1 \mathrm{H}, \mathrm{d}$, 4.5, H-2), $3.69\left(3 \mathrm{H}, \mathrm{s}, 8-\mathrm{O}-\mathrm{CH}_{3}\right), 3.90(1 \mathrm{H}, \mathrm{t}, 4.5, \mathrm{H}-3)$, $3.99\left(3 \mathrm{H}, \mathrm{s}, 4^{\prime}-\mathrm{O}-\mathrm{CH}_{3}\right), 6.64(1 \mathrm{H}, \mathrm{d}, 4.5, \mathrm{H}-4), 6.81(1 \mathrm{H}, \mathrm{d}$, $\left.8.3, \mathrm{H}-3^{\prime}\right), 6.85(1 \mathrm{H}, \mathrm{d}, 9.0, \mathrm{H}-6), 6.97\left(1 \mathrm{H}, \mathrm{d}, 7.5, \mathrm{H}-7^{\prime}\right)$, $7.00\left(1 \mathrm{H}, \mathrm{d}, 8.3, \mathrm{H}-2^{\prime}\right), 7.03(1 \mathrm{H}, \mathrm{d}, 9.0, \mathrm{H}-7), 7.39(3 \mathrm{H}, \mathrm{m}$, phenyl group of MTPA), $7.43\left(1 \mathrm{H}, \mathrm{t}, 7.5, \mathrm{H}-6^{\prime}\right), 7.71(2 \mathrm{H}$, $\mathrm{m}$, phenyl group of MTPA), $7.84\left(1 \mathrm{H}, \mathrm{d}, 7.5, \mathrm{H}-5^{\prime}\right)$.

\section{(S)-MTPA Ester (4)}

A sample of $2(1.5 \mathrm{mg}, 3.7 \mu \mathrm{mol})$ was treated with (-)$(R)$-MTPACl (15 $\mu \mathrm{l})$ (Kanto Kagaku Co.), and the reaction mixture was processed by the same procedure as that just described to afford 4 (1.0 mg). Compound 4: white solid; TLC $R f$ value 0.4 (hexane/EtOAc $(1: 1)$ ); ${ }^{1} \mathrm{H}-\mathrm{NMR}$ (750 $\left.\mathrm{MHz}, \mathrm{CDCl}_{3}\right): 3.52\left(3 \mathrm{H}\right.$, br s, $-\mathrm{O}-\mathrm{CH}_{3}$ of MTPA), 3.64 $(1 \mathrm{H}, \mathrm{d}, 4.5, \mathrm{H}-2), 3.71\left(3 \mathrm{H}, \mathrm{s}, 8-\mathrm{O}-\mathrm{CH}_{3}\right), 3.76(3 \mathrm{H}, \mathrm{s}, 5-$ $\left.\mathrm{O}-\mathrm{CH}_{3}\right), 3.79(1 \mathrm{H}, \mathrm{t}, 4.5, \mathrm{H}-3), 3.98\left(3 \mathrm{H}, \mathrm{s}, 4^{\prime}-\mathrm{O}-\mathrm{CH}_{3}\right)$, $6.74(1 \mathrm{H}, \mathrm{d}, 4.5, \mathrm{H}-4), 6.78\left(1 \mathrm{H}, \mathrm{d}, 8.3, \mathrm{H}-3^{\prime}\right), 6.95(1 \mathrm{H}, \mathrm{d}$, 8.3, H-2'), $6.96(1 \mathrm{H}, \mathrm{d}, 9.0, \mathrm{H}-6), 6.96\left(1 \mathrm{H}, \mathrm{d}, 7.5, \mathrm{H}-7^{\prime}\right)$, $7.07(1 \mathrm{H}, \mathrm{d}, 9.0, \mathrm{H}-7), 7.37(3 \mathrm{H}, \mathrm{m}$, phenyl group of MTPA), $7.42\left(1 \mathrm{H}, \mathrm{t}, 7.5, \mathrm{H}-6^{\prime}\right), 7.62(2 \mathrm{H}, \mathrm{m}$, phenyl group of MTPA), $7.82\left(1 \mathrm{H}, \mathrm{d}, 7.5, \mathrm{H}-5^{\prime}\right)$.

\section{Antimicrobial Activity}

A MeOH soln of 1 (200 or $20 \mu \mathrm{g} / \mathrm{ml}$ ) was added to paper disks ( $15 \mu$ l on a 6 -mm diameter paper disk), and the disks were dried for 30 minutes in a clean bench. The disks were then placed on agar media that had been inoculated with each of the test microorganisms (Arthrobacter paraffineus
ATCC21220, Brevibacterium sp. JCM6894, Staphylococcus aureus IFO12732, Bacillus subtilis IFO3134, Cytophaga marinoflava IFO14170, Pseudovibrio sp. MBIC3368, Escherichia coli IFO3301, Pseudomonas aeruginosa IFO3446, Candida albicans IFO1060, and Saccharomyces cervisiae ATCC27202). Halo formation was observed after 48 hours of incubation at $30^{\circ} \mathrm{C}$.

\section{Cytotoxicity}

A549 cells (a human lung cancer cell line) and Jurkat cells (a human leukemia cell line) were purchased from Dainippon Sumitomo Pharma Co. The A549 cells were cultured in Dulbecco's modified Eagle's medium (DMEM) containing $10 \%$ fetal bovine serum. The cells were seeded in a flat-bottomed 96-well microplate at a density of 4,000 cells $/ 200 \mu \mathrm{l} / \mathrm{well}$, and then cultured in an incubator $(5.0 \%$ $\mathrm{CO}_{2}$ - air) at $37^{\circ} \mathrm{C}$ for 14 hours. Serially diluted samples were added to each well, and the cells were cultured for a further 48 hours. The number of living cells was counted by the Alamar Blue ${ }^{\mathrm{TM}}$ assay according to the provided procedure. The $\mathrm{IC}_{50}$ value was determined as the concentration of a test compound that inhibited the number of living cells by $50 \%$ compared to the blank control. The Jurkat cells were cultured in an RPMI 1640 medium containing $10 \%$ fetal bovine serum. The $\mathrm{IC}_{50}$ value for the Jurkat cells was determined by the same procedure as that used for the A549 cells, except that the seeded density of the Jurkat cells was 2,000 cells $/ 200 \mu \mathrm{l} /$ well.

\section{Results}

\section{Taxonomy}

Colonies on PDA plates reached $47 \sim 60 \mathrm{~mm}$ diameter, floccose to deplanate with radiately sulcate, brown to greyish brown (5E-4 to 5E-3). Colonies on MA reached $53 \sim 56 \mathrm{~mm}$ diameter, floccose to plane, olive (3E-F-8). Colonies on OA reached $60 \sim 65 \mathrm{~mm}$ diameter, floccose, light orange to orange white (5A-5 to $5 \mathrm{~A}-2)$. Colonies on LcA reached $55 \sim 65 \mathrm{~mm}$ diameter, floccose, light orange to orange white (5A-5 to $5 \mathrm{~A}-2$ ). Colonies on CMA reached 35 37 mm diameter, deplanate, white (1A-1). Conidiomata are pycnidial, superficial and immersed in the center of colonies on PDA and CMA, globose, dark brown. Conidiogenous cells are phialidic, doliiform to ampulliform, hyaline, $7 \sim 10 \times 2 \sim 3 \mu \mathrm{m}$. Conidia are ellipsoidal to oblong, mainly two-celled (rarely threecelled), hyaline, $3 \sim 5 \times 1.5 \sim 2 \mu \mathrm{m}$. On these characteristics, strain NGB4 was identified as anamorphic genera Ascochyta [7], the fungus being tentatively designated as Ascochyta sp. NGB4. 
Table 1 Physico-chemical properties of ascochytatin (1)

\begin{tabular}{|c|c|}
\hline Appearance & Colorless needle \\
\hline Melting point & $227 \sim 229^{\circ} \mathrm{C}$ (decomp.) \\
\hline Molecular weight & 366 \\
\hline Molecular formula & $\mathrm{C}_{20} \mathrm{H}_{14} \mathrm{O}_{7}$ \\
\hline ESI-MS (positive) & $384\left(\mathrm{M}+\mathrm{H}_{2} \mathrm{O}\right)^{+}$ \\
\hline (negative) & $365(\mathrm{M}-\mathrm{H})^{-}$ \\
\hline HRFAB-MS (negaitive) & $\begin{array}{l}\text { found: } 365.0658 \\
\text { calcd : } 365.0661\left(\mathrm{C}_{20} \mathrm{H}_{13} \mathrm{O}_{7}\right)\end{array}$ \\
\hline$[\alpha]_{D}^{25}$ & $-153^{\circ}$ (c $\left.0.2, \mathrm{MeOH}\right)$ \\
\hline UV $\lambda_{\max } \mathrm{nm}(\log \varepsilon)$ in $\mathrm{MeOH}$ & $211(4.71), 311(4.10), 339$ (3.85) \\
\hline $\mathrm{IR} v_{\max }(\mathrm{KBr}) \mathrm{cm}^{-1}$ & $3481,3430,3328,1611,1519,1478,1419$ \\
\hline TLC $^{a}$ Rf value & $0.30\left[\mathrm{CHCl}_{3} / \mathrm{MeOH}(10: 1)\right]$ \\
\hline & 0.41 [hexane/EtOAc (1:2)] \\
\hline
\end{tabular}

a Silica gel 60 F254, Merck.

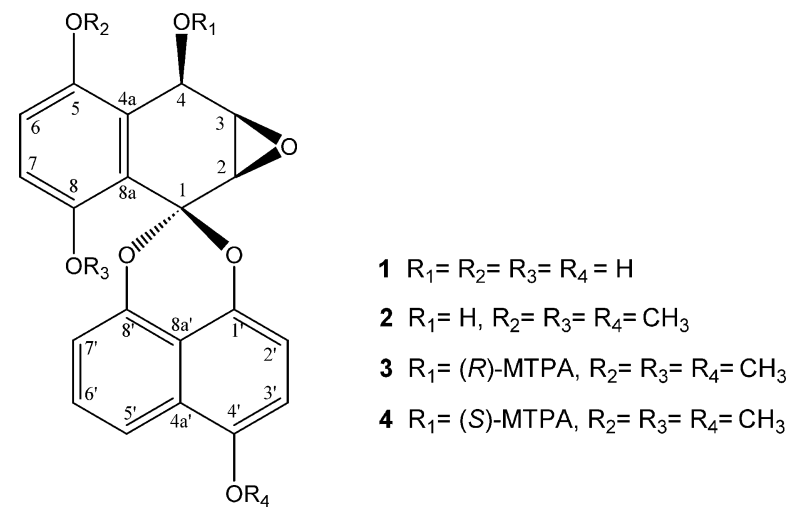

Fig. 1 Structures of ascochytatin (1) and its derivatives (2, 3 and $\mathbf{4})$.

\section{Structural Determination}

Ascochytatin (1) was obtained from the culture extract of the marine-derived fungus, Ascochyta sp. NGB4. The physico-chemical properties of $\mathbf{1}$ are summarized in Table 1. The molecular formula was determined to be $\mathrm{C}_{20} \mathrm{H}_{14} \mathrm{O}_{7}$ from the HRFAB-MS and ${ }^{13} \mathrm{C}-\mathrm{NMR}$ data. The ${ }^{13} \mathrm{C}-\mathrm{NMR}$ spectrum showed twenty resolved signals, of which sixteen aromatic carbons and three O-bearing aliphatic carbons were observed, while the remaining one $\left(\delta_{\mathrm{C}} 100.29\right)$ could be an acetal carbon. The ${ }^{1} \mathrm{H}-\mathrm{NMR}$ spectrum showed ten signals corresponding to ten protons. The remaining four protons were exchangeable and must be hydroxyl group protons $(-\mathrm{OH})$. All direct ${ }^{1} \mathrm{H}-{ }^{13} \mathrm{C}$ connections were determined by an HSQC experiment. An analysis of ${ }^{1} \mathrm{H}-{ }^{1} \mathrm{H}-\mathrm{COSY}$ data indicated four spin systems; three aromatic parts (Fig. 2a, c and d) and an aliphatic moiety (Fig. 2b) were obvious. An epoxide group in the aliphatic moiety was presumed from the ${ }^{1} \mathrm{H}$ - and ${ }^{13} \mathrm{C}$ - chemical

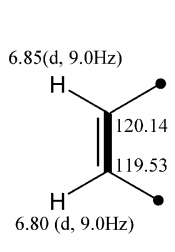

a

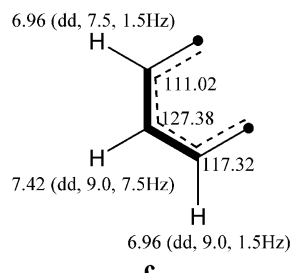

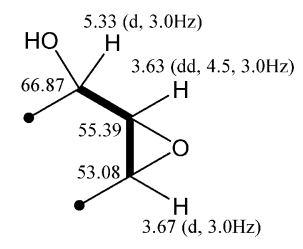

b

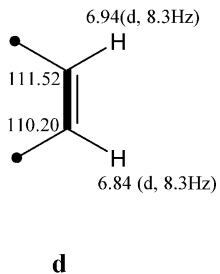

Fig. 2 Partial structures determined from COSY. 
Table 2 NMR spectral data of 1 in $\mathrm{CD}_{3} \mathrm{OD}$.

\begin{tabular}{|c|c|c|c|}
\hline Position & $\delta_{C}{ }^{a}$ & $\delta_{\mathrm{H}}(J \text { in } \mathrm{Hz})^{\mathrm{a}}$ & $\mathrm{HMBC}(\mathrm{H} \rightarrow \mathrm{C})$ \\
\hline 1 & 100.29 & & \\
\hline 2 & 53.08 & $3.67(1 \mathrm{H}, \mathrm{d}, 4.5)$ & $1,3,4,8,8 a$ \\
\hline 3 & 55.39 & $3.63(1 \mathrm{H}, \mathrm{dd}, 4.5,3.0)$ & $2,4,4 a$ \\
\hline 4 & 66.87 & $5.33(1 \mathrm{H}, \mathrm{d}, 3.0)$ & $4 a, 5,8 a$ \\
\hline $4 a$ & 122.09 & & \\
\hline 5 & 151.00 & & \\
\hline 6 & 120.14 & $6.85(1 \mathrm{H}, \mathrm{d}, 9.0)$ & $4,4 a, 8,8 a$ \\
\hline 7 & 119.53 & $6.80(1 \mathrm{H}, \mathrm{d}, 9.0)$ & $1,4 a, 5,8 a$ \\
\hline 8 & 151.28 & & \\
\hline $8 a$ & 118.45 & & \\
\hline $1^{\prime}$ & 140.22 & & \\
\hline $2^{\prime}$ & 111.52 & $6.94(1 \mathrm{H}, \mathrm{d}, 8.3)$ & $5^{\prime}, 8^{\prime}, 8 a^{\prime}$ \\
\hline $3^{\prime}$ & 110.20 & $6.84(1 \mathrm{H}, \mathrm{d}, 8.3)$ & $4 a^{\prime}, 5^{\prime}, 8{ }^{\prime}, 8 a^{\prime}$ \\
\hline $4^{\prime}$ & 150.11 & & \\
\hline $4 a^{\prime}$ & 126.78 & & \\
\hline $5^{\prime}$ & 117.32 & $7.82(1 \mathrm{H}, \mathrm{dd}, 9.0,1.5)$ & $1^{\prime}, 2^{\prime}, 4 a^{\prime}, 5^{\prime}, 8^{\prime}, 8 a^{\prime}$ \\
\hline $6^{\prime}$ & 127.38 & $7.42(1 \mathrm{H}, \mathrm{dd}, 9.0,7.5)$ & $1^{\prime}, 2^{\prime}, 4^{\prime}, 4 a^{\prime}, 8 a^{\prime}$ \\
\hline $7^{\prime}$ & 111.02 & $6.96(1 \mathrm{H}, \mathrm{dd}, 7.5,1.5)$ & $1^{\prime}, 4^{\prime}$ \\
\hline $8^{\prime}$ & 149.02 & & \\
\hline $8 a^{\prime}$ & 115.19 & & \\
\hline
\end{tabular}

${ }^{a}$ Residual solvent signals are used as internal standards $\left(\delta_{\mathrm{H}} 3.31\right.$ for $\mathrm{CHD}_{2} \mathrm{OD}, \delta_{\mathrm{C}} 49.15$ for $\mathrm{CD}_{3} \mathrm{OD}$ )

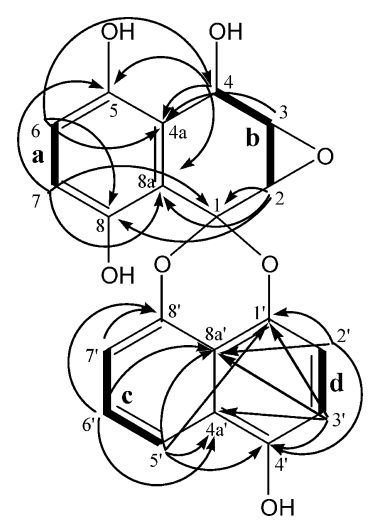

Fig. 3 Planar structure of $\mathbf{1}$ deduced from HMBC.

Bold lines show spin systems from COSY, which correspond to the partial structures $a, b, c$ and $d$ in Fig. 2, and arrows indicate $\mathrm{HMBC}$ signals.

shifts. The planar structure of $\mathbf{1}$ shown in Fig. 3 was deduced from the HMBC signals, and the NMR data are summarized in Table 2. Compound 1 was a $1^{\prime}, 4^{\prime}, 8^{\prime}$ trihydroxynaphthalene unit connected by a spiroacetal (via $1^{\prime}$ and $8^{\prime}$ hydroxy groups) to another partially reduced and functionalized naphthalene unit.

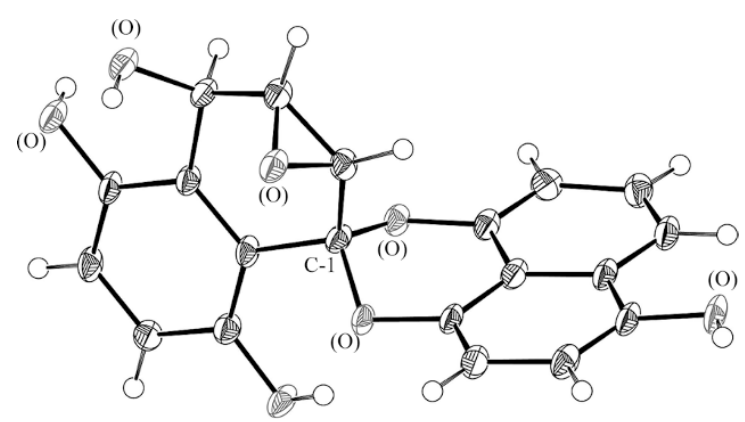

Fig. 4 ORTEP drawing of $\mathbf{1}$.

An X-ray crystallographic analysis was conducted to confirm the structure and determine the relative stereochemistry. A suitable crystal, whose crystal parameters and refinement parameters are described in the Materials and Methods section, was obtained by crystallization from $\mathrm{MeOH}$. An ORTEP drawing is shown in Fig. 4, the X-ray analysis validating the structure deduced by NMR experiments and also allowing us to establish the relative configuration.

The modified Mosher's method [8] was employed to determine the absolute stereochemistry of $\mathbf{1}$. The three 
phenolic and naphtholic hydroxy groups $(5-\mathrm{OH}, 8-\mathrm{OH}$, and $\left.4^{\prime}-\mathrm{OH}\right)$ of $\mathbf{1}$ were initially methylated by trimethylsilyldiazomethane to avoid signal complexity, and

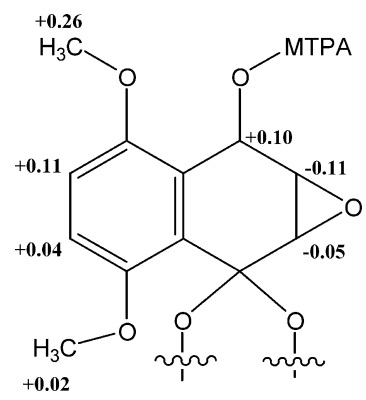

Fig. $5 \Delta \delta\left(\delta_{(S) \text {-MTPAester }}-\delta_{(R) \text {-MTPA ester }}\right)$ values for the MTPA esters of $\mathbf{2}$.

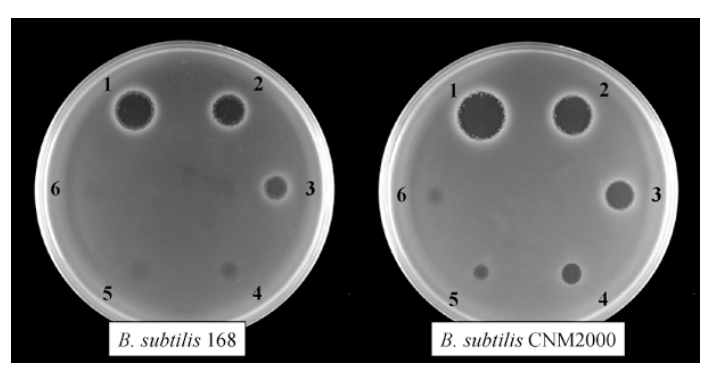

Fig. 6 Sensitivity of Bacillus subtilis 168 and CNM2000 to 1.

The differential inhibitory activity of $\mathbf{1}$ against B. subtilis 168 and CNM2000 was investigated. One microliter of the DMSO solution of $\mathbf{1}$ at six concentrations $(\mu \mathrm{g} / \mathrm{ml})$ was spotted on Trypticase Soy agar plates containing B. subtilis 168 or CNM2000: 1000 (1), 500 (2), 250 (3), 125 (4), 62.5 (5), 31.3 (6). then the trimethylated derivative (2) was further converted to the $(R)$ - or $(S)$-MTPA ester (3 or $\mathbf{4}$, respectively). The protons of each derivative were assigned by ${ }^{1} \mathrm{H}-\mathrm{NMR}$, COSY, HSQC and HMBC data. The key $\Delta \delta\left(\delta_{\mathrm{S}}-\delta_{\mathrm{R}}\right)$ values are shown in Fig. 5, indicating that the absolute configuration of C-4 was $R$. The absolute stereochemistry was therefore determined as shown in Fig.1.

\section{Sensitivity of $B$. subtilis 168 and CNM2000 to 1}

The sensitivity of B. subtilis 168 and CNM2000 to 1 was examined. As shown in Fig. 6, 1 exhibited stronger activity against $B$. subtilis CNM2000 than against wild-type strain 168, as aranorosinol B did [5]. The difference in sensitivity to 1 between $B$. subtilis 168 and CNM2000 suggests that $\mathbf{1}$ inhibited the function of TCS (YycG/YycF) in B. subtilis.

\section{Antimicrobial Activity and Cytotoxicity}

The antimicrobial activity was investigated by the paper disk method, the result being presented in Table 3 . Compound 1 exhibited relatively strong and specific activity against Gram-positive bacteria and C. albicans. The cytotoxicity of $\mathbf{1}$ to mammalian cancer cells was also investigated, compound $\mathbf{1}$ exhibiting cytotoxicity to both A549 and Jurkat cells with respective $\mathrm{IC}_{50}$ values of 4.8 and $6.3 \mu \mathrm{M}$.

\section{Discussion}

Ascochytatin (1) was found by a screening method using B. subtilis 168 and its temperature-sensitive mutant, CNM2000, which could differentiate the TCS inhibitors

Table 3 Antimicrobial activity of (1)

\begin{tabular}{|c|c|c|c|}
\hline \multirow{2}{*}{ Taxon } & \multirow{2}{*}{$\begin{array}{c}\text { Tested strain } \\
\text { Strain }\end{array}$} & \multicolumn{2}{|c|}{ Halo diameter $(\mathrm{mm})^{\mathrm{a}}$} \\
\hline & & $3 \mu \mathrm{g} / \mathrm{disk}$ & $0.3 \mu \mathrm{g} / \mathrm{disk}$ \\
\hline \multirow[t]{2}{*}{ Actinobacteria } & Arthrobacter paraffineus ATCC21220 & 8 & - \\
\hline & Brevibacterium sp. JCM6894 & 18 & 7 \\
\hline \multirow[t]{2}{*}{ Firmicutes } & Staphylococcus aureus IFO 12732 & 11 & 7 \\
\hline & Bacillus subtilis IFO 3134 & 17 & 10 \\
\hline Bacteroidetes & Cytophaga marinoflava IFO 14170 & - & - \\
\hline Alphaproteobacteria & Pseudovibrio sp. MBIC3368 & - & - \\
\hline \multirow[t]{2}{*}{ Gammaproteobacteria } & Escherichia coli IFO 3301 & - & - \\
\hline & Pseudomonas aeruginosa IFO3446 & - & - \\
\hline \multirow[t]{2}{*}{ Yeast } & Candida albicans IFO 1060 & 16 & 11 \\
\hline & Saccharomyces cerevisiae ATCC27202 & - & - \\
\hline
\end{tabular}

a - : No activity. 
[5]. The structure of $\mathbf{1}$ was determined by spectroscopic methods, including MS and NMR. The relative stereochemistry was determined by an X-ray crystallographic analysis, and the absolute configuration was determined by the modified Mosher's method. Compound 1 was shown to be a $1^{\prime}, 4^{\prime}, 8^{\prime}$-trihydroxynaphthalene unit connected by a spiroacetal to another partially reduced and functionalized naphthalene unit as shown in Fig. 1. Although more than twenty structurally related compounds having a spirodioxynaphthalene unit in the molecule, e.g. cladospirone bisepoxide [9], CJ-12,371 and CJ-12,372 [10], Sch 49210 and its related compounds [11], palmarumycins [12], diepoxins [13], and decaspirones [14], have been reported, 1 is the sole compound being oxidized at $4^{\prime}$ position of the naphthalene unit.

The earlier study found that aranosinol B exhibited differential activity between B. subtilis 168 and CNM2000, and completely inhibited $\mathrm{YycG}$ autophoshorylation at $50 \mu \mathrm{g} / \mathrm{ml}$. Although 1 exhibited almost the same differential activity againt $B$. subtilis 168 and CNM2000 as aranosinol B did, the inhibitory activity of $\mathbf{1}$ for $\mathrm{YycG}$ autophosphorylation was quite week (unpublished result). Studies on the detailed mechanism of action of $\mathbf{1}$ are being undertaken.

Acknowledgments We thank Professor R. Sakai of Kitasato University for the FAB-MS measurements and Ms. T. Sasaki for her technical assistance. We also thank Mr. T. Kiyuna and M. Nishijima of TechnoSuruga Laboratory Co., LTD. for the taxonomic studies of the fungus. This work was performed as part of the project entitled "Construction of a Genetic Resource Library of Unidentified Microorganisms" supported by New Energy and Industrial Technology Development Organization (NEDO). This work was supported in part by the Research and Development Program for New Bio-industry Initiatives (2006-2010) from the Bio-oriented Technology Research Advancement Institution (BRAIN).

\section{References}

1. Barrett JF, Hoch JA. Two-component signal transduction as a target for microbial anti-infective therapy. Antimicrob Agents Chemother 42: 1529-1536 (1998)

2. Barrette JF, et al. Antibacterial agents that inhibit twocomponent signal transduction systems. Proc Natl Acad Sci USA 95: 5317-5322 (1998)

3. Macielag MJ, Goldschmidt R. Inhibitions of bacterial two- component signaling systems. Exp Opin Invest Drugs 9: 2351-2369 (2000)

4. Matsushita M, Janda KD. Histidine kinases as targets for new antimicrobial agents. Bioorg Med Chem 10: 855-867 (2002)

5. Watanabe T, Hashimoto Y, Yamamoto K, Hirao K, Ishihama A, Hino M, Utsumi R. Isolation and characterization of inhibitors of the essential histidine kinase, YycG in Bacillus subtilis and Staphylococcus aureus. J Antibiot 56: 1045-1052 (2003)

6. Kornerup A, Wanscher JH. Methen handbook of colour, 3rd ed., Eyre Methen, London, UK. (1978)

7. Sutton BC. The Coelomycetes-fungi imperfecti with pycnidia acervuli and stoma-, CAB International, Wallingford, UK. (1980)

8. Ohtani I, Kusumi T, Kashman Y, Kakisawa H. High-field FT NMR application of Mosher's method. The absolute configurations of marine terpenoids. J Am Chem Soc 113: 4092-4096 (1991)

9. Thiergardt R, Hug P, Rihs G, Peter HH. Cladospirone bisepoxide - a novel fungal metabolite structure determination. Tetrahedron Lett 35: 1043-1046 (1994)

10. Sakemi $\mathrm{S}$, Inagaki $\mathrm{T}$, Kaneda $\mathrm{K}$, Hirai $\mathrm{H}$, Iwata $\mathrm{E}$, Sakakibara T, Yamaguchi Y, Norcia M, Wondrack LM, Sutcliffe JA, Kojima N. CJ-12,371 and CJ-12,372, two novel DNA gyrase inhibitors. Fermentation, isolation, structural elucidation and biological activities. J Antibiot 48: 134-142 (1995)

11. Chu M, Truumees I, Patel MG, Gullo VP, Blood C, King I, Pai JK, Puar MS. A novel class of antitumor metabolites from the fungus Nattrassia mangiferae. Tetrahedron Lett 35: 1343-1346 (1994)

12. Krohn K, Michel A, Florke U, Aust HJ, Draeger S, Schulz B. Palmarumycins $\mathrm{C}_{1} \sim \mathrm{C}_{16}$ from Coniothyrium sp.: isolation, structure elucidation, and biological activity. Liebigs Ann Chem: 1099-1108 (1994)

13. Schlingmann G, West RR, Milne L, Pearce CJ, Carter GT. Diepoxins, novel fungal metabolites with antibiotic activity. Tetrahedron Lett 34: 7225-7228 (1993)

14. Jiao P, Swenson DC, Gloer JB, Campbell J, Shearer CA Decaspirones $A \sim E$, bioactive spirodioxynaphthalenes from the freshwater aquatic fungus Decaisnella thyridioides. J Nat Prod 69: 1667-1671 (2006) 